\title{
Effect of different suture materials on healing of blood vessels in dogs
}

\author{
O.H. Al-Hyani, A.Kh. Al-Jobory and A.M. Al-Hasan
}

Department of Surgery and Theriogenology, College of Veterinary Medicine, University of Mosul, Mosul, Iraq

\begin{abstract}
The objective of this study was to evaluate the use of 3 types of non absorbable suture materials in arteries and veins suturing. Twelve adult dogs of both sexes was used, the animals was divided into three groups of four animals in each. The right common carotid artery and left jugular vein of each animal was used for application of suture materials. In group one the blood vessels (common carotid artery and jugular vein) sutured with polypropylene suture after inducing about $2 \mathrm{~cm}$ longitudinal incision on the vessel, in group two polyester suture was used in the same manner of group one, while in group three myo-steel suture was used in the same way of group one and two. The macroscopic and microscopic changes associated with each suture material were studied at 15 and 30 postoperative days. The gross pathological changes associated with polypropylene was that of very mild adhesion and very mild shrinkage and stenosis at the suture line with smooth blood flow, while the groups of polyester and myo-steel suture associated with severe adhesions, shrinkage at the suture line with poor blood flow. The histopathological changes showed that polypropylene suture lead to formation of very few amount granulation tissue at the line of incision, no signs of organized thrombus formation or significant changes of the blood vessels wall, but the polyester suture cause arterial organized thrombus formation and hypertrophy of endothelial wall, while the myo-steel suture lead to formation intense amount granulation tissue which cause to the thickening in the wall of blood vessels with subsequent changes in the normal shape of vessels. In conclusion the polypropylene suture was regarded better and superior than polyester and myo-steel suture materials in blood vessels surgery.
\end{abstract}

Keywords: Suture materials; healing; blood vessels; dog. Available online at http://www.vetmedmosul.org/ijvs

$$
\begin{aligned}
& \text { تأثير خيوط جراحية مختلفة على التئام الأوعية الدموية في الكلاب } \\
& \text { أسامة حازم ألحياني، أحمد خلف الجبوري وعبدالحليم مولود الحسن } \\
& \text { فرع الجر احة و علم تناسل الحيوان، كلية الطب البيطري، جامعة الموصل، الموصل، العراق }
\end{aligned}
$$

الهدف من أجر اء هذه الدراسة لمعرفة تأثثر بعض الخيوط الجراحية الغير ممتصة على التنام الأوعية الدموية والمتمثلة بالثريان

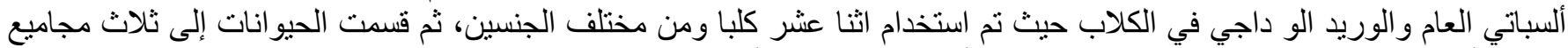

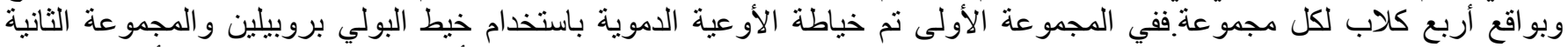

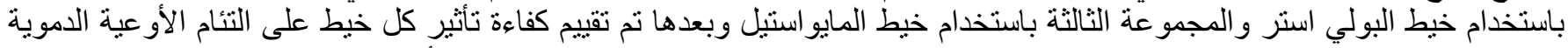
من خلال دراسة التغير ات العينية و النسيجية لكل خيط كل

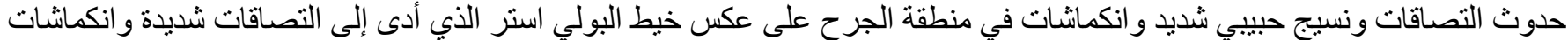

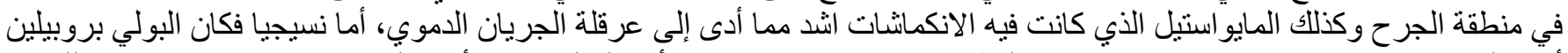

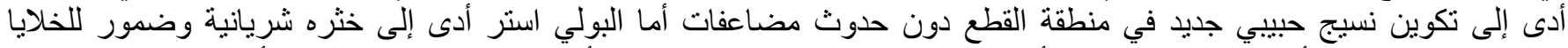

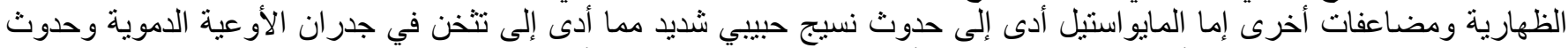
تغيير شديد في الثكل الطبيعي للأوعية الدموية. ونستتج أن خيط البولي بروبيلين هو أفضل من خيط البولي استر والمايواستيل عل التئام 


\section{Introduction}

Vascular surgery deals with blood vessels, these vessels can vary in size and length (1). Bleeding associated with surgery is potentially serious complication, so hemostasis to prevent blood loss is commonly achieved by tying a surgical thread around the blood vessel (2). Peripheral vascular diseases that are amenable to surgery are rare in dogs, those encountered most commonly have been arteriovenous fistula and systemic arterial embolism (3). The blood vessels may be injured accidentally by trauma such as in bite, car accident, wire and during venesuction, also in many instances ruptured blood vessels can be occurred and treated by ligation $(2,4)$. The wall of the blood vessel several portions when seen in cross-section. There is an outer layer or adventitia on its exterior surface, a central portion or media, and a surface lining of cells or intima on its luminal or interior surface (4). There are different types of suture threads that are being used for tissue closure in different types of surgeries and invasive procedures (5). Natural absorbable materials are absorbed by proteolysis, which causes a significant inflammatory response while synthetic absorbable materials are absorbed by hydrolysis, which minimizes such reactions (6). In present day user qualities of biological inert, synthetic, absorbable, and non absorbable threads have approaching the limit of the requirements imposed by modern surgery (7). The suture material used in vascular surgery should have some properties these includes no capillarity and least thrombogenic characters, the monofilament materials such as polypropylene, braided polyester and silk are most commonly used in vascular surgery particularly in the presence of infection (8). Because the selection of an ideal suture material for blood vessels surgery is a controversial point, our present study is designed to compare between three suture materials for closing of incised common carotid artery and jugular vein in dogs and these includes: polypropylene, polyester and myo-steel suture materials, and the study including gross and histopathological changes associated with the application of these sutures.

\section{Materials and methods}

Twelve adult dogs of both sexes were used and divided into three groups of four animals in each as follow: Group one: polypropylene suture $(2 / 0)$ was used. (Ethicon inc. USA). Group two: polyester suture $(2 / 0)$ was used. (Ethicon inc. USA). Group three: myo-steel suture $(2 / 0)$ was used. (E\&A Medical Corporation USA).

The right common carotid artery and left jugular vein was used for application of these suture materials.

Anesthesia:-All the animals are premedicated with atropine sulfate $(0.05 \mathrm{mg} / \mathrm{kg}$ i.m. $)$ and anesthetized after 15 min. with a mixture of xylazine and ketamine $(2 \mathrm{mg} / \mathrm{kg}$ and $10 \mathrm{mg} / \mathrm{kg}$, i.m., respectively)

Surgical operation:- After anesthetization of animals the cervical region was prepared for aseptic surgery, a $5 \mathrm{~cm}$ skin incision induced on the jugular groove at both sides of the cervical region, and by blunt dissection the left jugular vein and the right common carotid artery was identified and occluded from two sides by the use of two non crushing, rubber clamp to provide good homeostasis from the site of incision then about $2 \mathrm{~cm}$ longitudinal incision was induced on the jugular vein and common carotid artery between the crushing clamps, after that the incision was closed by simple continuous technique and by using polypropylene in group one, polyester in group two and myo-steel suture in group three. After suturing the crushing clamps was removed to allow flow of blood, the subcutaneous and the skin were closed routinely. The gross pathological study and biopsy collection was performed on 2 animals of each group at 15 postoperative day and the remaining animals at the 30 postoperative day.

\section{Results}

\section{Cross changes}

Group one: After 15 days, polypropylene suture was produced minimal granulation tissue and adhesion between the suture line and the surrounding tissues with minimal shrinking in the diameter of the vessels, also there was no any signs of leakage (figure 1), while after 30 days,was showed complete absence of adhesion with return the diameter of vessels to its normal size with normal blood flow (figure 2).

Group two: suturing the vessels with polyester suture after 15 days was lead to sever granulation tissue and adhesion formation with shrinking in the diameter of the vessels at the site of the suture line that's lead to abnormal blood flow, also no any signs of leakage was present (figure 3 ), but after 30 days the adhesion was markedly reduces and the diameter of vessels return to relatively normal size (figure 4).

Group three: the myo-steel suture after 15 days from suturing the vessels was showed moderate to severe adhesion with surrounding tissue with more shrinking in the diameter of vessels at the suture line, also there is no any signs of leakage (figure 5), while the sings after 30 days was characterized by absence or less adhesion formation compare with the 15 days and return the diameter of vessels nearly to its normal size (figure 6).

\section{Histopathological changes}

Suturing the jugular vein with polypropylene suture after 15 postoperative days was lead to the granulation tissue formation (collagen fiber, fibroblast and newly blood vessels) and edema with highly vascularization, infiltration 
of little mononuclear inflammatory cells was also present (figure7), while after 30 postoperative days, the granulation tissue was reduced relatively with presence newly veinuoles, there was edema and infiltration of mononuclear inflammatory cells was shown and the endothelial cells became hypertrophy with vaculation in the intima (figure 8).

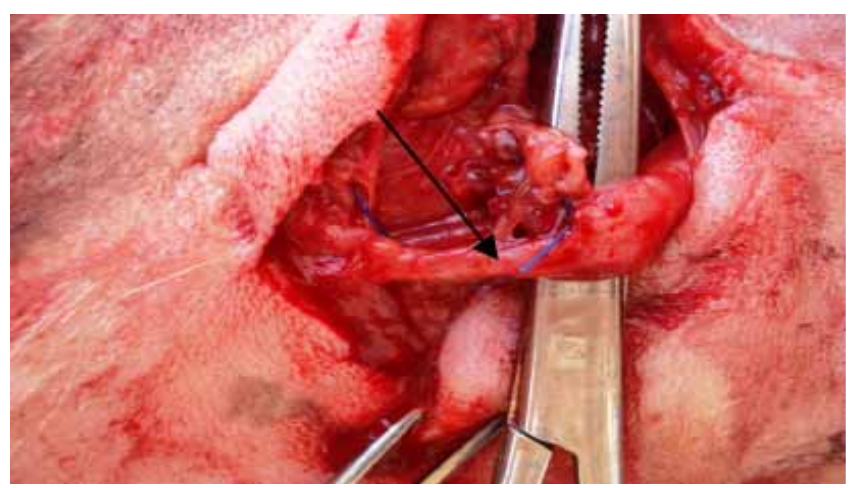

Figure1: show the site of suturing of blood vessels with Polypropylene after 15 days.

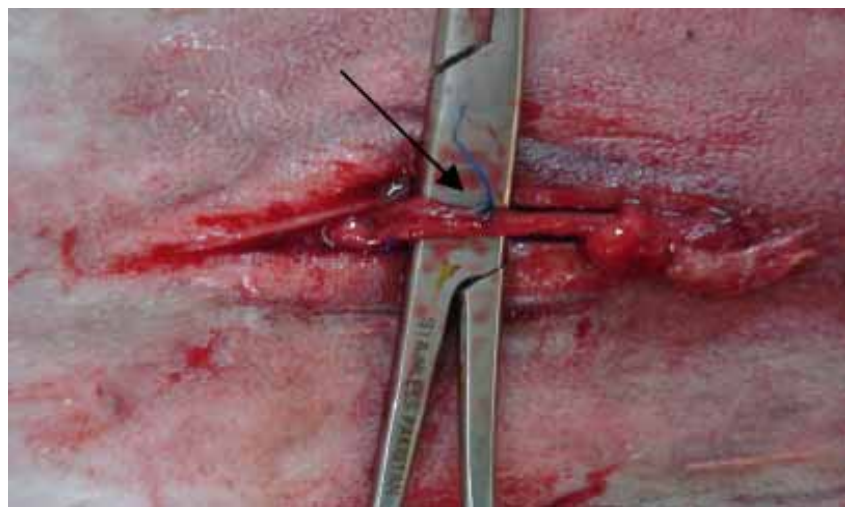

Figure2: show the site of suturing of blood vessels with Polypropylene after 30 days.

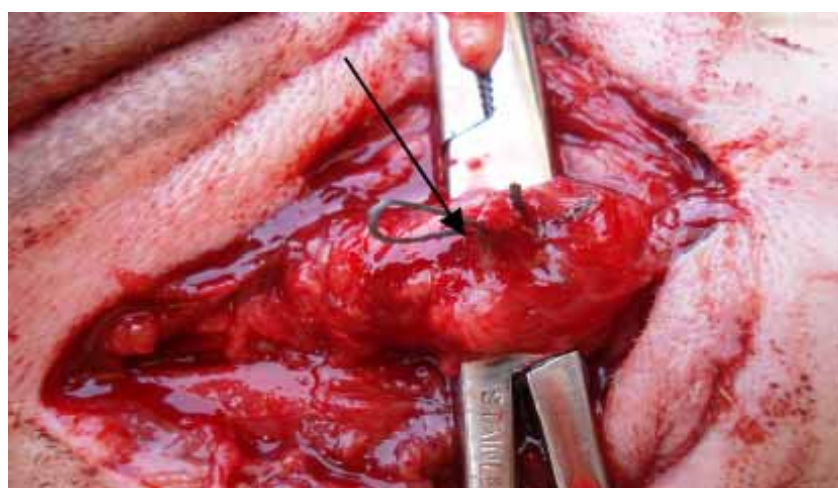

Figure3: show the site of suturing of blood vessels with polyester after 15 days.

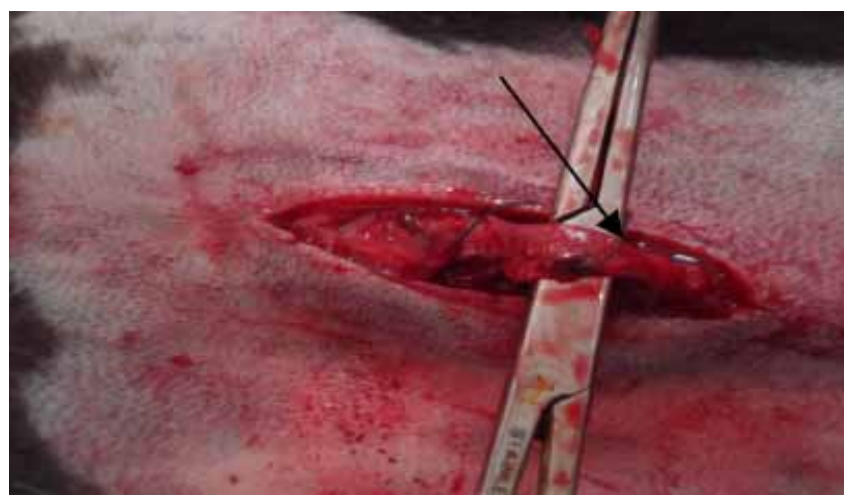

Figure 4: show the site of suturing of blood vessels with polyester after 30 days.

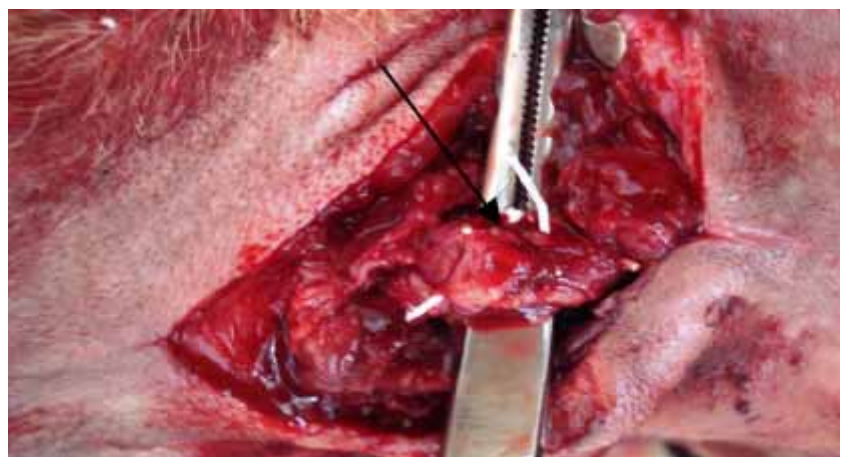

Figure5: show the site of suturing of blood vessels with myo steel after 15 days.

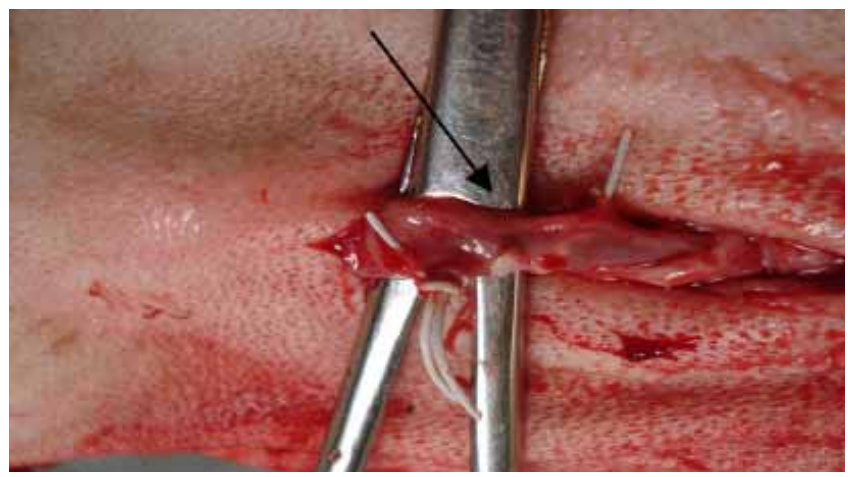

Figure 6: show the site of suturing of blood vessels with myo steel after 30 days.

In the Common carotid artery after 15 postoperative days there was infiltration of little mononuclear inflammatory cells with proliferation in the collagen fiber and fibroblast in the tunica intima and it is extended to the tunica media and adventitia with the thickening in the tunica media and replacement the fibrous tissue with muscle fiber (granulation tissue formation), some elastic 
fiber was suffered from fragmentation and duplication (figure9). The changes that occur after 30 postoperative days, was similar to that show at 15 postoperative days but the granulation tissue was reduced relatively.

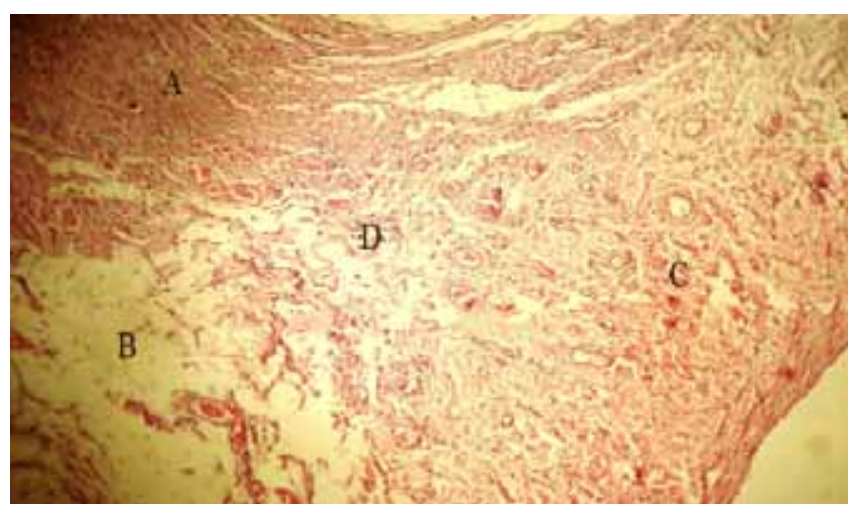

Figure 7: photomicrograph of J.V. suturing with Polypropylene in dog after 15 postoperative days show formation granulation tissue (A), edema (B), highly vascularization (C) and infiltration of mononuclear inflammatory cells (D) (H\&E 90X).

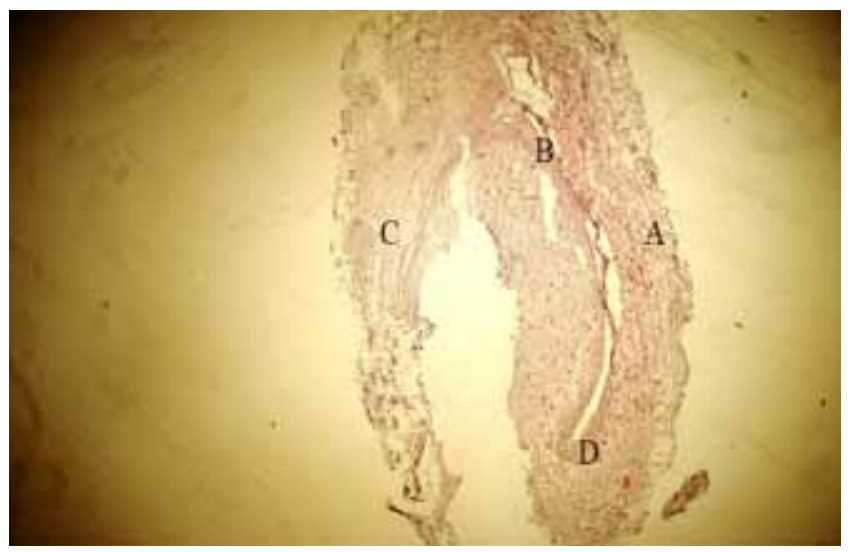

Figure 8: photomicrograph of J.V. suturing with Polypropylene in dog after 30 postoperative days show granulation tissue (A), edema (B) infiltration of mononuclear inflammatory cells (C) and hypertrophy of endothelial cells (D) (H\&E 35X).

Polyester suture in the jugular vein after 15 postoperative days was caused granulation tissue formation in the intima and its extend to the media, edema was formed with sever infiltration of mononuclear inflammatory cells and newly blood vessels (figure 10), while after 30 postoperative days there was reducing in the granulation tissue in the intima and media, edema, sever infiltration of mononuclear inflammatory and congestion of veinuoles was shown. In the common carotid artery after 15 postoperative days, the suture was caused organized thrombus formation. The fibrous tissue was proliferated in tunica intima and extend to the media and the tunica intima was became thickened, and hypertrophy of the endothelial cells, edema was formed with infiltration of mononuclear inflammatory cells This suture caused relatively disorientation of the normal structure of the artery (figure 11), while after 30 postoperative days, the organized thrombus in the lumen was became adherent to the wall of artery (intima) due to fibrin formation. The collagen fibers and fibroblast was proliferated the tunica intima and media, this edema and infiltration of mononuclear inflammatory cells was present with sever fatty infiltration in the vascular smooth muscle (figure 12).

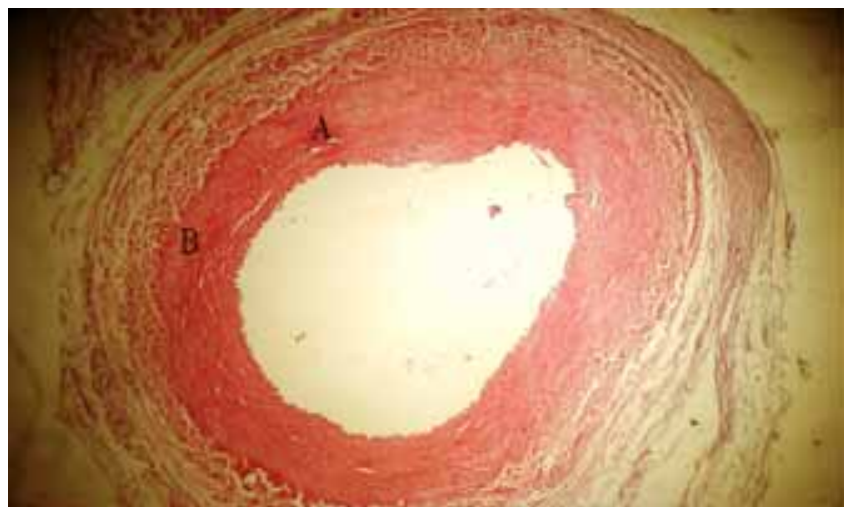

Figure 9: photomicrograph of C.C.A. suturing with Polypropylene in dog after 15 postoperative days show newly granulation tissue formation (A) and infiltration of mononuclear inflammatory cells (B) (H\&E $35 \mathrm{X})$.

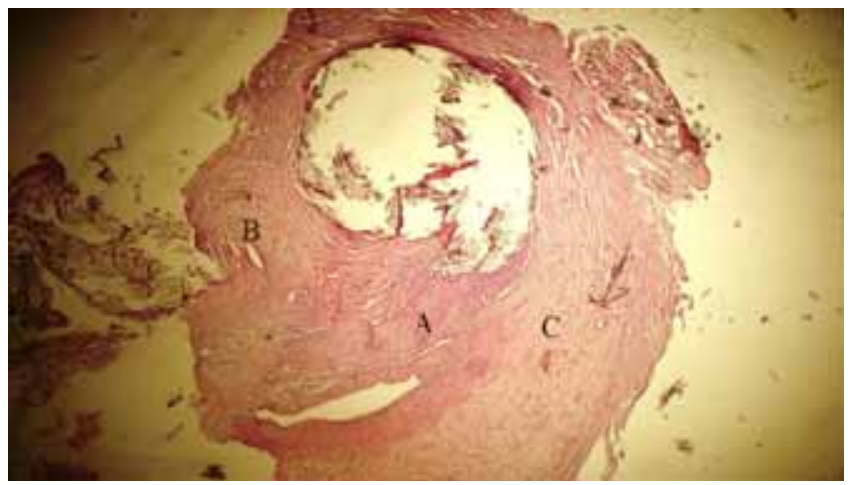

Figure10: photomicrographof J.V. suturing with Polyester in $\operatorname{dog}$ after 15 postoperative days show formation granulation tissue (A) edema (B) and sever infiltration of mononuclear inflammatory cells (C) (H\&E $35 \mathrm{X})$.

In myo-steel suture, after 15 postoperative days, the wall of the jugular vein was thickened due to formation of 
granulation tissue with edema and vaculation formation (figure 13), but after 30 postoperative days, the granulation tissue was reduced, edema and sever infiltration of inflammatory cells was shown. While the effects of this suture after 15 postoperative days in the common carotid artery was characterized by thickening in the wall of the artery due to fibrous connective tissue formation with sever hyalinization and vaculation in the endothelium (figure 14), but after 30 postoperative days the suture was caused thickening in wall of the artery with loss of the normal architecture due to formation of granulation tissue, also showed extension of fibrous bulge to the lumen of artery with sever vaculation and infiltration of mononuclear inflammatory cells (figure 15).

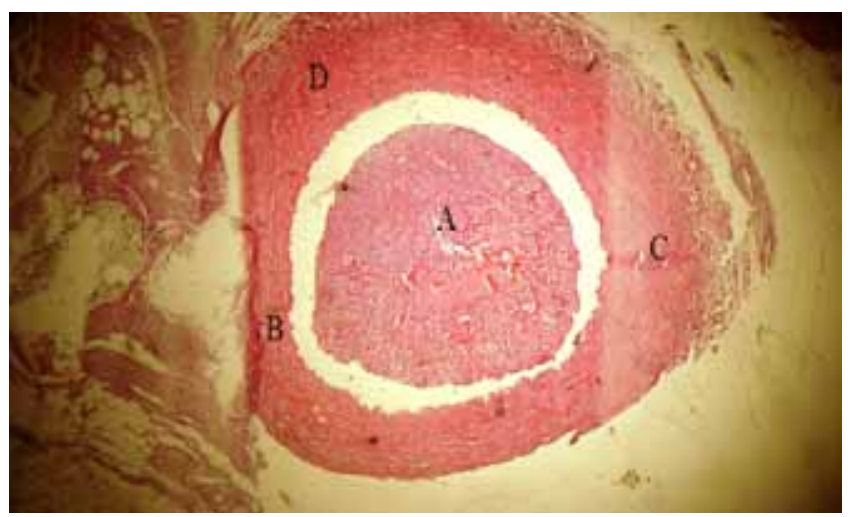

Figure11: photomicrographof C.C.A. suturing with Polyester in dog after 15 postoperative days show organized thrombus (A) granulation tissue (B) hypertrophy of endothelial cells (C) and edema (D) (H\&E 35X).

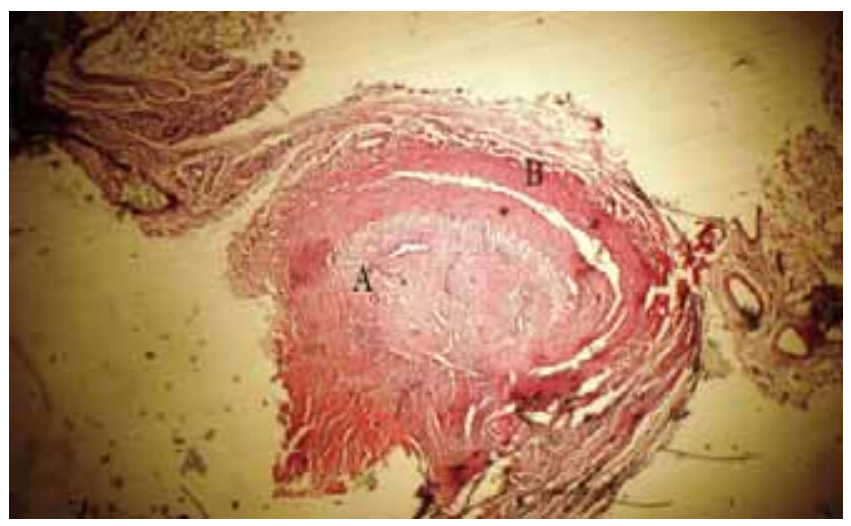

Figure 12: photomicrographof C.C.A. suturing with Polyester in dog after 30 postoperative days show adherent the organized thrombus to the lumen of artery wall (A) and sever fatty infiltration (B) (H\&E 35X).

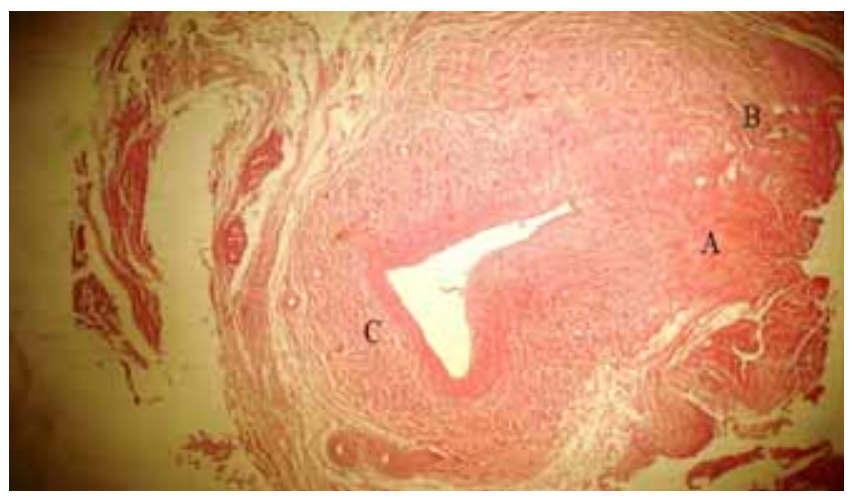

Figure13: photomicrographof J.V. suturing with Myo-steel in dog after 15 postoperative days show granulation tissue (A), infiltration of mononuclear inflammatory cells (B) and edema (C) (H\&E $35 \mathrm{X})$.

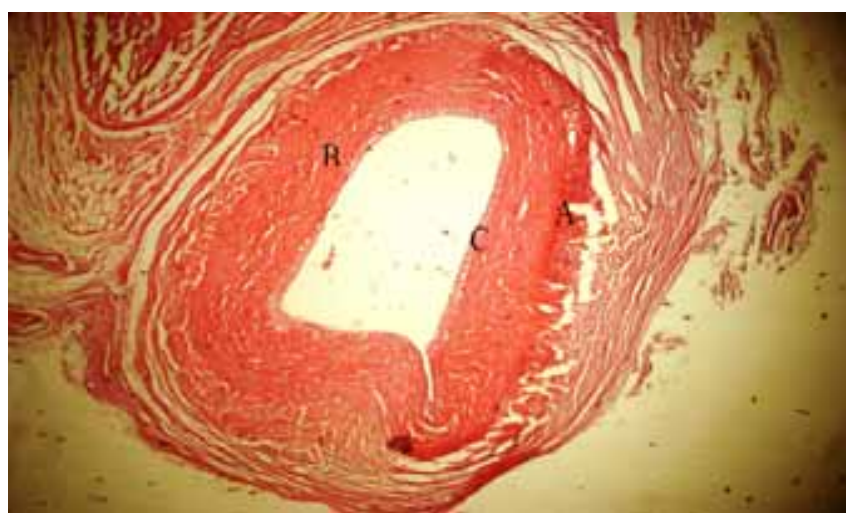

Figure14: photomicrographof C.C.A. suturing with Myosteel in dog after 15 postoperative days show granulation tissue (A), hyalinization (B) and endothelium vaculation (C) (H\&E 35X).

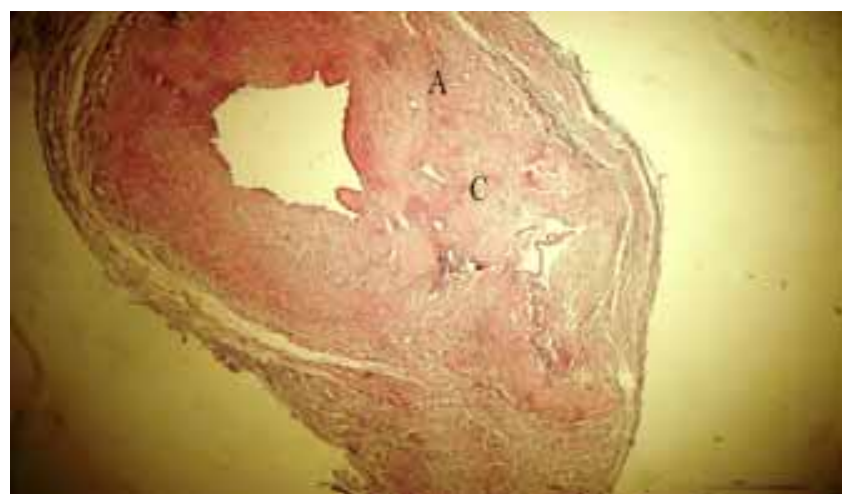

Figure 15: photomicrographof C.C.A. suturing with Myosteel in dog after 30 postoperative days show granulation tissue (A), fibrous bulge (B) and infiltration of mononuclear inflammatory cells (C) (H\&E 35X). 


\section{Discussion}

The gross and histopathological changes and biomechanical properties of suture materials in blood vessels surgery was studied experimentally and clinically $(9,10)$. Development of infection, oozing, and scar at the incision following suturing are among the main concerns that surgeons, always raises the question about which suture should be used avoid such problems (5). In this study a non absorbable suture material was used because, cardiovascular surgeons have been always reluctant to use absorbable suture material for arterial and venous surgery because of suspected anastomotic dilatation or even rupture during and after the absorption phase (11), while other workers found no significant differences between the polypropylene and absorbable suture material for arterial femoral artery in dogs (12). The narrowing of the blood vessels at the site of suturing in this experiment was suspected because even with the most careful placement of suture in linear or circumferential repair of blood vessels the narrowing cannot be avoided (13). This study revealed that polypropylene preserved the diameter of the blood vessels to nearly normal one, this matches the result of other workers when they compare between polypropylene and polyester sutures $(9,14)$. In this study the histopathological changes associated with the suture materials like endothelial injury, endothelial proliferation, media vaculation and reaction around suture material was reported by other workers (10). The thrombus formation in the site of suturing was sporadically developed in this experiment, this thrombus may results from the presence of Intraluminal suture material and local vessel injury, and because of large caliber vessels was used in this study the thrombogenicity may be overcome by massive blood flow (15). In conclusion all the three suture materials used in this study can be applied for vascular surgery with the priority of polypropylene suture.

\section{References}

1. Slatter DH.Textbook of Small Animal Surgery.W.B. Saunders Company,Philadelphia,USA. 1985;1102-1106.

2. Hoglund OV, Hagman Olsson K, Mindemark J, Borg N, Lagerstedt A.S. A. New re absorbable device for ligation of blood vessels- A pilot study. Acta Veterin. Scandina. 2011; 53: 47-54.

3. Perkins RL and Edmark KW. Ligation of femoral vessels and az yous vein in the dog. JAVMA.1979;159:993

4. Berge $\mathrm{E}$ and Westhues $\mathrm{M}$. Veterinary operation surgery.medical book Company,Bailliere,USA. 1977; pp:37 -67.

5. Spotnitz WD, Falstrom JK, Rodeheaver GT. The role of suture threads and fibrin sealant in wound healing. Surg Clin North Am.1997;77:651-669.(Abstract)

6. Saleh F, Palmieri B, Lodi D, Al-Sebeih K. An innovative method to evaluate the suture compliance in sealing the surgical wound lips. Int J Med Sci. 2008; 6: 354-360.

7. Chennakkattu K, Sadasivan P, Sharma CP. Review paper: Absorbable polymeric surgical sutures: Chemistry, Production, Properties, Biodegradability, and Performance. J Biomat Appli. 2010; 25: 1-77.

8. Persia RD, Guzman A, Rivera L and Vazquez J. Mechanisms of biomaterials:sutures after the surger applications of engineering mechanics in medicine, GED - University of Puerto Rico, Mayaguez. 2005;PP:1-27

9. Norbert B, Dobrin PB, Mark M, Dong QS, Mrkvicka R. Influence of suture technique and suture material selection on the mechanics of end-to-end ansd end-to-side Anastomosis. J Thorac Cardiovasc Surg. 1996; 111: 1063-1072.

10. Radad K, and El-Shazly M. Clinical and pathological assessment of different suture techniques for microvascular Anastomosis in rat femoral artery. J Vet Sci. 2007; 3: 269-273.

11. Karl-Heinz $O$ and Schmitz-Rexin T. Absorbable suture material in vascular surgery. Endovascular Surg. 1993; 6: 413-424.

12. Gersak, B. Comparison between absorbable and non absorbable sutures in arterial Anastomosis in growing dogs. J Cardiovasc Surg. 1991; 6: 757-760.

13. Healy JE, Clark R L, Gallanger HS, O'Neill P, Sheena KS. Non suture repair of blood vessels. Annals Surg. 1962; 6: 817-825.

14. Tozzi P, Ayoz H, Ruchat A, Corno C, Oedman U, Botta Von-Sgesser L.K. Animal model to compare the effects of suture techniques on cross-sectional compliance on end-to-side Anastomosis. Europ J Cardio-thoacic Surg. 2001; 19: 477-481.

15. Chlupac J, Filova E, Bacakova L. Blood vessels replacement: 50 years of Developmental and Tissue Engineering in Vascular Surgery. Physiol Res 2009; 2: 119-130. 